\title{
ASSESSMENT OF TRAINING NEEDS AND COMPETENCE LEVEL OF EXTENSION WORKERS IN KANO STATE, NIGERIA
}

\author{
${ }^{* 1}$ Tafida, I., ${ }^{1}$ Yusuf, A. K., ${ }^{2}$ Kabir, A. M. and ${ }^{1}$ Abdullahi, A. \\ ${ }^{1}$ Department of Agricultural Economics and Extension, Bayero University, Kano. \\ ${ }^{2}$ Department of Agricultural Education, Adamu Tafawa Balewa College of Education, Kangere, Bauchi. \\ *Corresponding Author: itafida.ext@buk.edu.ng
}

\begin{abstract}
The study assessed the competence level and skills gap of extension agents in Kano State, Nigeria. Three (3) Local Government Areas were purposively selected from each of the three administrative zones making a total of nine Local Government Areas. A total of 117 extension agents were randomly selected and data were collected using structured questionnaires. Descriptive statistics, Training Needs Analysis and SWOT Analysis were used to analyse the data. The study revealed that extension services in the study area were male dominated $(88.9 \%)$ and more than two third obtained Ordinary and Higher National Diplomas. Extension workers were found to understand the organizations' needs and had the impressions that issues of the organizations can be solved through training. The study further revealed that extension workers were competent in learning initiative and enterprises (3.41), team work (3.24), communication and problem solving (3.15) while they were found to be least competent in planning and organization (2.91) and leadership (2.96). The SWOT analysis found the strength and weakness of the extension workers as transferring of information through regular interactions with farmers (3.4) and having too many jobs with different specializations (3.12) while highest ranked opportunities and threats were good communication skills with farmers (3.44) and interference of politicians into technical aspects (3.41), respectively. Therefore, frequent professional and technical trainings, employment of more extension workers especially women, disengagement of politicians from technical aspects and collaboration with research institutes and universities would improve capacity and efficiency of extension service delivery in the study area.
\end{abstract}

Keywords: Competence, Level, Skills, Gap, Extension, Workers.

\section{INTRODUCTION}

Agricultural extension is an indispensable way for reaching farmers with required knowledge and advice they need to upgrade their livelihoods. Agricultural extension services enable and lubricates the transfer of information, knowledge and modern practices to farmers which they require in order to improve their yield and also the standard of their livelihoods. It is therefore necessary to provide farmers with adequate knowledge and information in the right ways and right time (Sadia, 2016, Sanga, Kalungwizi and Msuya, 2013). Agricultural extension is also described as the system of diffusing the latest ideas and methods to farming community in order to improve their conventional farming practices (Abbas, Lodhi, Bashir and Mahmood, 2008).

In 1974, the Agricultural Development Authority (ADA) system was institutionalized in Nigeria with funding assistance from the World Bank, Federal Government and State Governments (Omoregbee and Ajayi, 2009). The Kano ADP termed Kano Agricultural and Rural Development Agency
(KNARDA) has been in areas of improving agricultural services and human development. The agricultural extension agent is the one who examines the problems of the farmers and rural people and bring them back a suitable solution of such problem (Safdar, 2005).

For a successful and effective extension agent's job, there is need for the extension agent to be well-trained and competent in their jobs and these calls for a continuous in-service training. According to Saleh, et al., (2016), Training is the process of acquiring specific skills to perform a job better. It involves the processes of teaching, informing and educating people. This has led to increasing emphasis on the development of core competencies necessary for the extension agents to perform at maximum. Diverse and dynamic agricultural systems, advancing science and technologies, changing socio-demographics, increasing globalization and growing competition for resources demand agricultural extension professionals to be proficient in the technical aspects of their areas of expertise, as well as in the 
processes and delivery of the services. In other words, the need and demand for extension professionals to demonstrate a higher level of professionalism in their service are growing (Chikaire, et al. 2018). Training programs have to meet the espoused high training needs found in the training needs assessment. The training needs to be agreed on by both supervisors and intended beneficiaries should be implemented before other needs (Azizah, 2011). A training identification phase should precede any effort to provide a training program. For relevant, efficient and effective in-service training, identification of needs is necessary. Also, for any extension organization to improve its performance a continues and systematic training of its staff is necessary (FAO, 2001). It is difficult to designate the persons to be covered by training, training objectives, program content and the relevant methods without precise and objective training needs (Omoregbee, and Ajayi, 2009).

In developing countries, there is a high demand of a large number of well-trained extension agents (Crowder, 1996) as few extension agents serve thousands of farmers compared to develop ped countries (Due, Magayane and Temu, 1997). In the USA, Canada and Europe one extension agent covers about 400 farmers while in Africa, Asia, Latin America and Near East an extension agent covers about 2,500 active farmers (FAO, 1990). In a more recent study, the extension agent farmer ratio in Kenya is 1:753 while in Nigeria it raised from 1:1700 in 2008 to 1:3011 in 2012 (Haruna and Abdullahi, 2013). In order for the extension agents to serve such number of farmers effectively, there is need for them to be well trained in areas they are lacking so as to perform their job effectively. Extension agents need practical learning that provides them with opportunities to relate to rural people in an interactive process that put together scientific technical knowledge with local indigenous knowledge in client-centered problem-solving activities. There should be regular analysis of technical competence and job performance of extension agents to meet such demands (Yondeowei and Kwarteng, 2006). For organizational effectiveness and efficiency, training is mandatory. There are two major types of training programs: on-the-job training type which is given to an already employed individual that requires some skills and knowledge to improve efficiency; in-service training and induction courses were classified as on-the-job training. A change in technology is one of the things that lead to on-the-job training. The second type is the pre-employment training program which is given to an individual that has tentatively chosen a discipline but requires basic education to function effectively. (Ovwigho and Ifie, 2009).

Farmers are more likely to benefit better when they receive agricultural packages from well-trained, more equipped and up-to-date extension agents, therefore extension agents need in-service training to increase their work efficiency. Training needs design is a crucial point in order to increase the quality of agricultural extension services. Training of extension agents is a crucial part of the overall agricultural production process. Part of the duties of extension agents is to reach farmers scattered around the country with updates on useful and practical information so as to increase agricultural production (Ovwigho and Ifie, 2009).

The increasing changes in and demand for high quality and quantity of farm produce made on agriculturally based institutions and farmers in the 21 st century have had a considerable impact on roles and job performance of extension agents. As a result, the traditional subsistence agriculture is gradually been replaced by market-oriented or commercial agriculture. This is probably due to factors including rapid economic growth in both developing and developed countries, introduction of new technologies, market expansion, market liberalization, increased demand for food, decreasing farming population as result of urbanization, liberalized and open economic policies, bilateral and multilateral economic agreements, developed infrastructural facilities in farming areas and government agricultural policies (Mahaliyanaarachchi and Bandara, 2006).

The main objective of this study is to assess the skills gap and areas of training needs among extension workers in Kano State. The specific objectives are to;

- describe the socioeconomic characteristics of extension agents in the study area;

- examine the training needs of extension agents in the study area;

- assess the professional competence level of extension agents in the study area and

- determine the strengths, weaknesses, opportunities and threats of extension agents in the study area.

\section{MATERIALS AND METHOD}

\section{The Study Area}

Kano State is located in the north western part of Nigeria. It has a total land area of $20,131 \mathrm{~km}^{2}$ and lies between latitudes $11^{0} 30^{\prime}$ and $12^{0} 37^{\prime}$ North and longitudes $8^{0} 30^{\prime}$ and $9^{0} 20^{\prime}$ east. It is situated in the Sudan savannah agro ecological zone of Nigeria. It shares boundaries with Bauchi State to the south, Kaduna State to the southwest, Katsina State to the west and northwest and to the east and northeast Jigawa State (KNSG, 2008). The population of Kano stood at 11,058,300 and ranks first out of the 36 States of the Federation (NPC, 2006). Using the anticipated annual growth rate of $3.3 \%$, the population of Kano State is projected to be 13,648,026 in the year 2019. Kano State is located on the "high plains of Hausa land" with the occurrence of rock outcrops predominantly in the southern part of the State. The highest elevation is Riruwai in Doguwa Local Government Area, with a peak reaching up to 1,230 metres above sea level (Olofin, 1987).

The Agricultural Development Authority (ADA) system in Nigeria was institutionalized in 1974 with funding assistance 
from the World Bank, Federal and State Governments (Okeowo, 2015). The Kano State ADP is named Kano Agricultural and Rural Development Agency (KNARDA). Kano States has forty-four local governments and was categorized into three agricultural zones by KNARDA. Zone I Rano comprises of 14 LGAs which include; Rano, Tudun Wada, Doguwa, Bebeji, Kiru, Garun Malam, Kura, Kumbotso, Madobi, Gwarzo, Karaye, Rogo, Kibiya and Bunkure. Zone II Dambatta comprises of 13 LGAs which include; Dambatta, Bichi, Bagwai, Shanono, Tsanyawa, Kunchi, Kabo, Rimin Gado, Tofa, Makoda, Minjibir and Ungogo. While Zone III Gaya comprises of 17 LGAs namely; Gaya, Ajingi, Wudil, Albasu, Garko, Takai, Sumaila, Dawakin Kudu, Warawa,
Gezawa, Gabasawa, Kano Municipal, Gwale, Tarauni, Dala, Fagge and Nassarawa.

\section{Sampling Procedure}

Multistage sampling was used for this study. The first stage was the purposive selection of three Local Government Areas from each of the three agricultural zones in Kano State based on the intensity of agricultural activities which gave a total of (9) nine Local Government Areas. The second stage was the random selection of extension workers from each Local Government Area. The lists of extension workers in these Local Government Areas were used as sampling frame for the selection of the extension workers. Random sampling using random numbers was generated from Microsoft Excel to be used for selecting required respondents.

The sample size will be determined by a mathematical formula (Miller and Brewer, 2003);

$$
n=\frac{N}{1+N(\alpha)^{2}}
$$

Where;

$$
\mathrm{n}=\text { required sample size }
$$

$N=$ sample frame

$\alpha=$ margin of error (standard value of 0.08 ).

A simple proportion formula was then used to calculate the number of extension agents that will be interviewed in each local government using;

$y=\frac{x}{x} * N$ Equation 2

Where;

$\mathbf{y}=$ ward sample size

$\mathbf{x}=$ ward sample frame

$\mathbf{X}=$ total sample frame and

$\mathbf{N}=$ total sample size.

The below Table provides the sample size generated for the purpose of data collection:

Table 1: Sampling Frame and Sample Size of the Extension Agents

\begin{tabular}{lccr}
\hline Agricultural & Selected Local Government & Sample Frame & Sample Size \\
Zones & Areas & & 13 \\
\hline Zone I & Gwarzo & 25 & 24 \\
& Kura & 47 & 12 \\
\multirow{2}{*}{ Zone II } & Doguwa & 24 & 14 \\
& Dambatta & 26 & 12 \\
& Makoda & 23 & 11 \\
Zone III & Bagwai & 21 & 10 \\
& Gaya & 20 & 14 \\
& Warawa & 27 & 7 \\
\hline Total & Takai & 13 & 117 \\
\hline
\end{tabular}

Source: Field Survey, 2019

\section{Data Collection Procedure}

Primary data was collected using structured questionnaire which was designed in respect of the objectives of the study. The questionnaire was administered to extension agents in the study area. The questionnaire answer questions including; demographic characteristics, training needs, competence level, skill gap of extension agents and also the strengths, weaknesses, opportunities and threats faced by the extension agent in the study area.

\section{Tools of Analysis}

To achieve the objectives of the study, the following tools were used; 
1. Descriptive Statistics

2. Training Needs Analysis

3. SWOT Analysis

\section{Model Specification}

Training Needs Analysis

Training needs analysis was used in identifying areas of need for training of extension agents in the study area. Techniques or methods that are used for training needs analysis include performance appraisal, interviews, questionnaires, tests, analysis of behaviour, informal talks, checklist, counseling, critical incidents, recording, surveys, and observations.

\section{SWOT Analysis}

SWOT analysis will be used to determine the strengths, weaknesses, opportunities and threats of extension agents in the study area. SWOT analysis is a strategic planning technique for identifying the strengths, weaknesses, opportunities and threats in an organization. It helps in pointing out the specific skills, knowledge and behaviour needed to achieve organizational objectives.

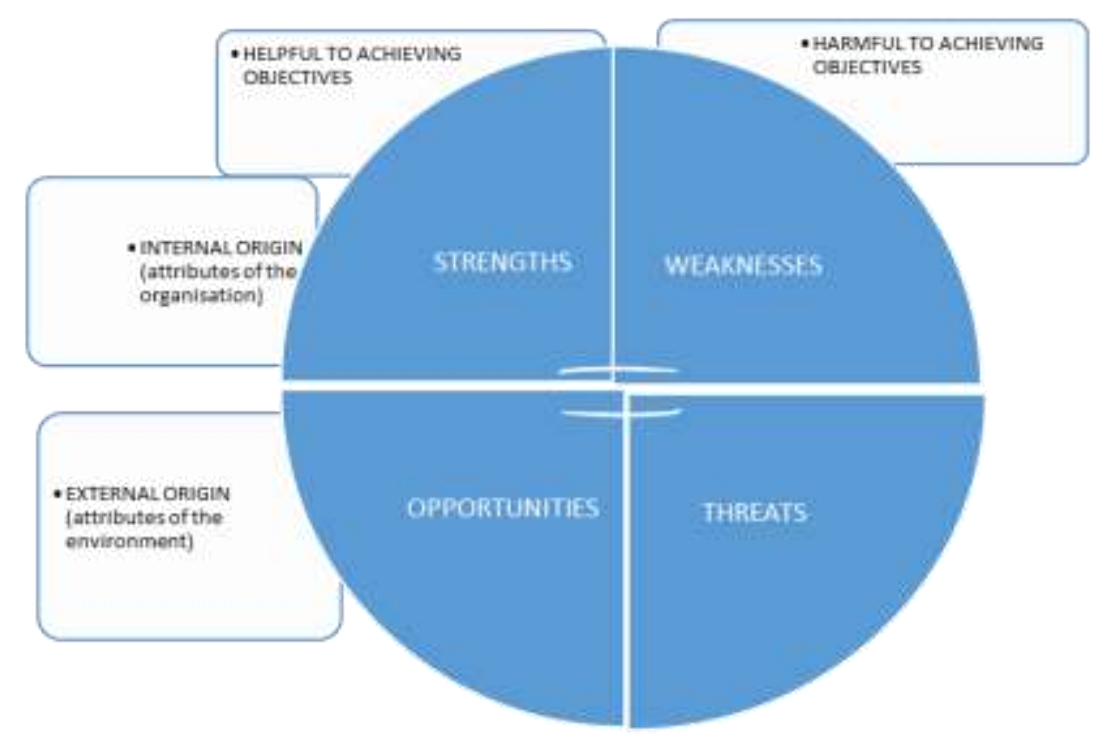

Figure 1: Components of SWOT Analysis.

\section{RESULTS AND DISCUSSION}

Sex of Extension Workers

As shown in Figure 2, majority $(89 \%)$ of the respondents were males while $(11.1 \%)$ were female. This shows that extension services in Kano State are male dominated which is in line with the findings of a study by Okeowo (2015) on Analysis of Competency and Training Needs among Agricultural Extension Personnel in Lagos State. He reported that $74 \%$ of the extension workers in his work were males. There is need for more female participation in the extension work due to continues increase of women farmers. 


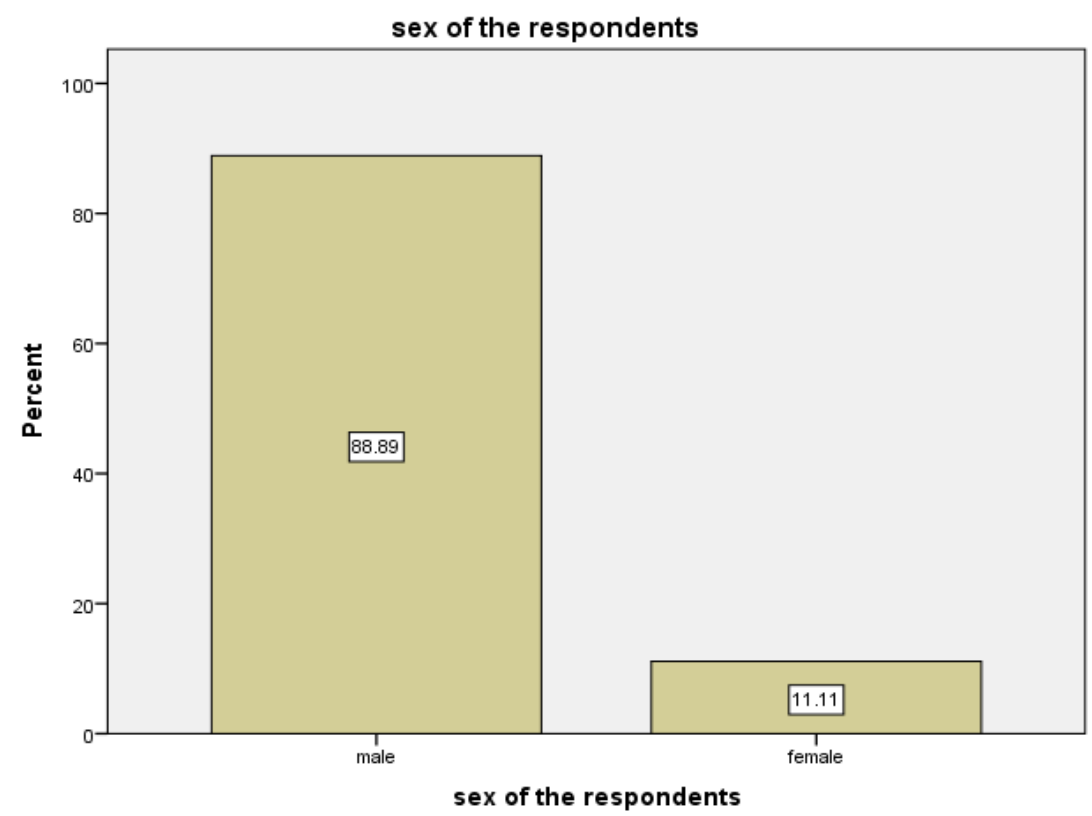

Figure 2: Sex of the Extension Workers

\section{Level of Education of Extension Workers}

Figure 3 revealed that about a third of the extension workers (36.8\%) had HND as their highest qualification attained, which was followed by Diploma (35\%), NCE (14.5\%), Degree (7.7\%) and SSCE (6\%). This contradicts with the results of Omoregbee and Ajayi (2009) who reported that $55.3 \%$ of the respondents had OND in a study carried out in Edo State. This shows that there is an improvement in the level of education of the extension agents from OND to HND.

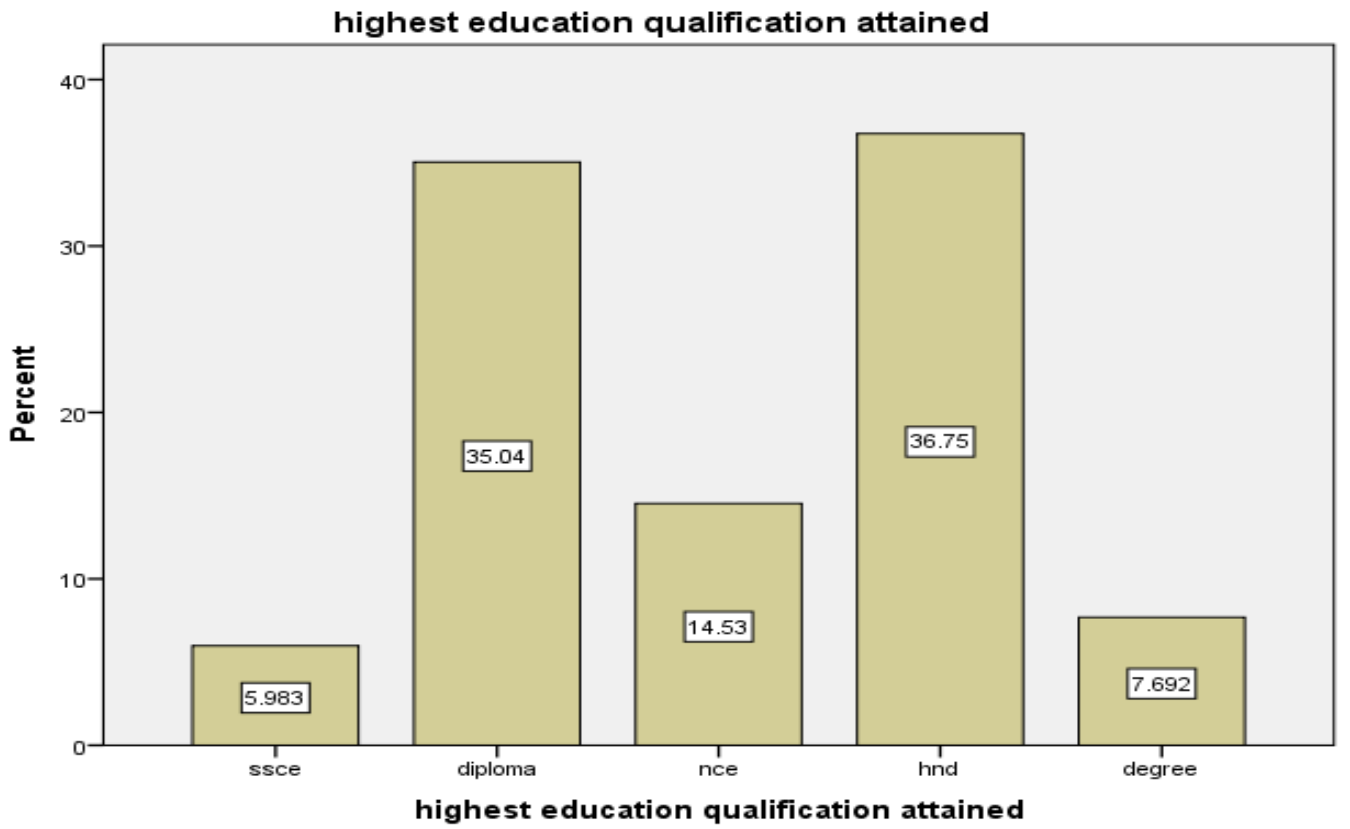

Figure 3: Highest Education Qualification Attained by the Extension Workers

Age of Extension Agents

Most (49.6\%) of the respondents were between the age of 24-34 years, followed by those between 35-45 years (32.5\%) and the least age group was between 55-65 years (17.9\%). 


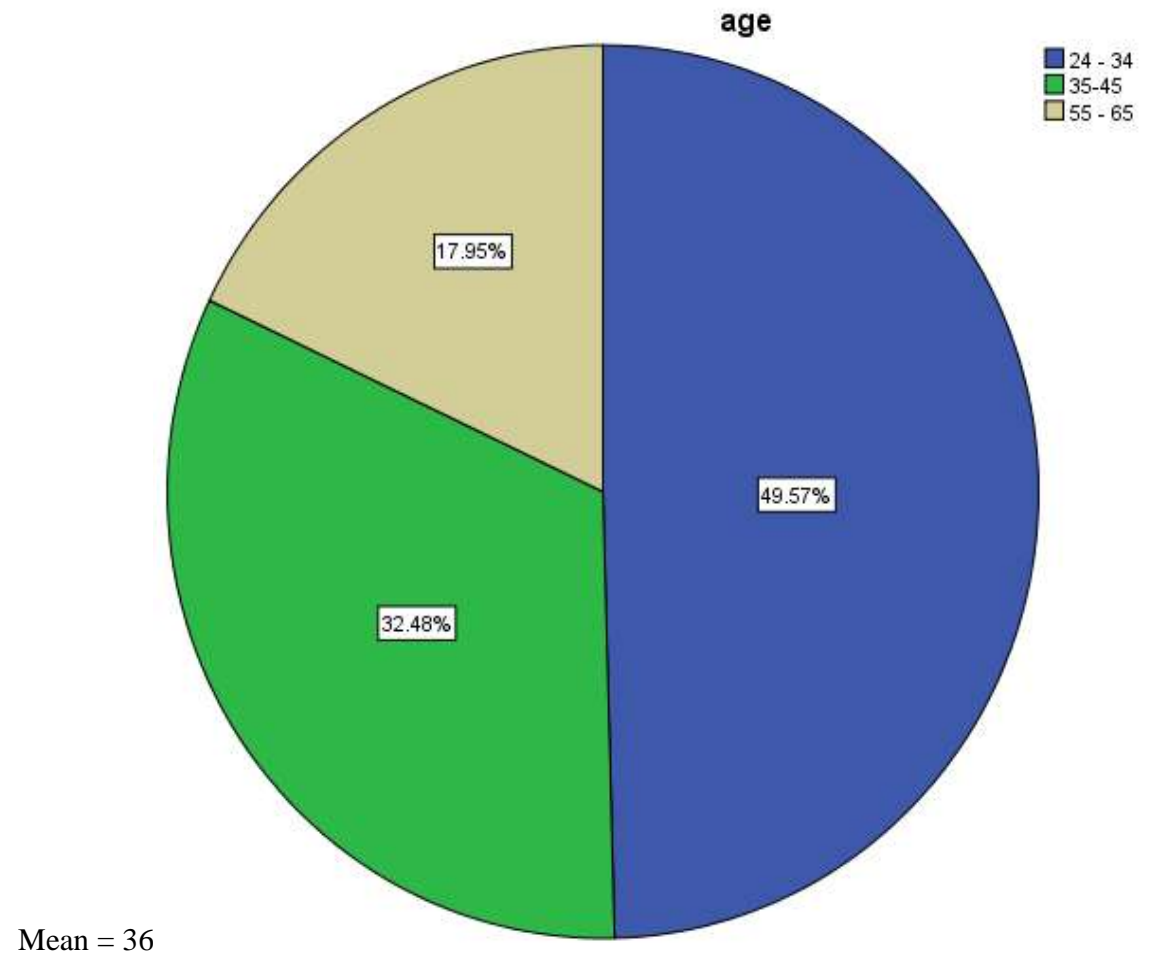

Figure 4: Ages of Extension Agents

Results from Figure 4 shows the distribution of the age of the respondents based on percentage. Nearly half (49.6\%) of the respondents are between the age of $24-30$ years with the mean age as 36 years. This shows that the extension agents were young and training acquired can be used for a long period of time in service. This is also in line with Okeowo (2015) who reported that most $(43.8 \%)$ of the respondents in his research were between the age of 20-30 years.

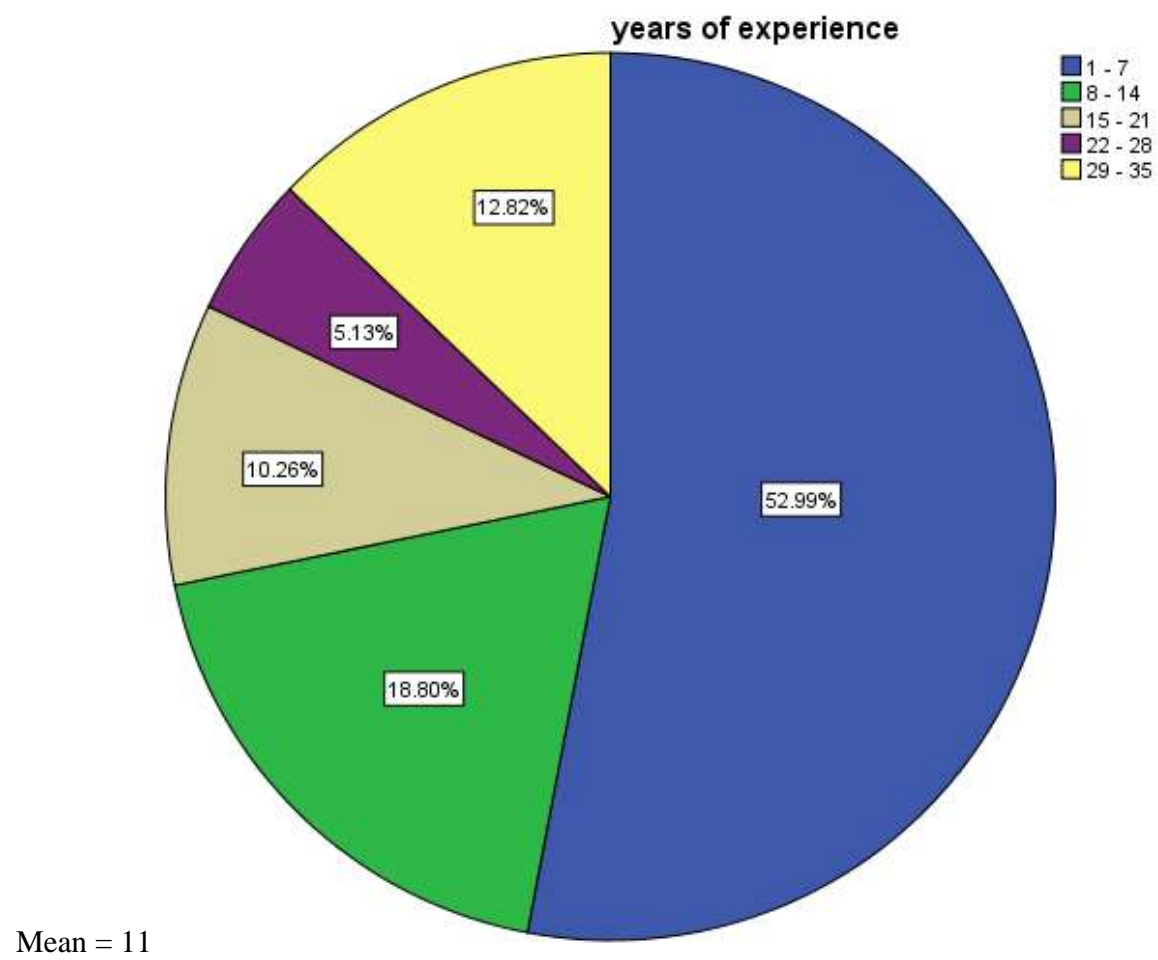


Figure 5: Years of Professional Experience of Extension Agents

More than half $(53 \%)$ of the respondents had $1-7$ years of experience and also a mean of 11 years. This is in line with the findings of Lalhma and Devarani (2016) and Okeowo (2015) who reported that $61.1 \%$ and $80 \%$ of the respondents had 3-6 and 1 - 10 years of working experience. The low years of working experience can be a factor that will make the extension agents demand for more training so as to improve their job performance.

\section{Number of Trainings Attended by Extension Agents}

Figure 6 shows that the highest number of respondents (54.7\%) attended 1-5 numbers of trainings and $22.2 \%$ attended $6-10$ professional trainings. The remaining attended $11-15(12.9 \%), 16-20(5.17 \%)$ and $21-25(5.1 \%)$ trainings.

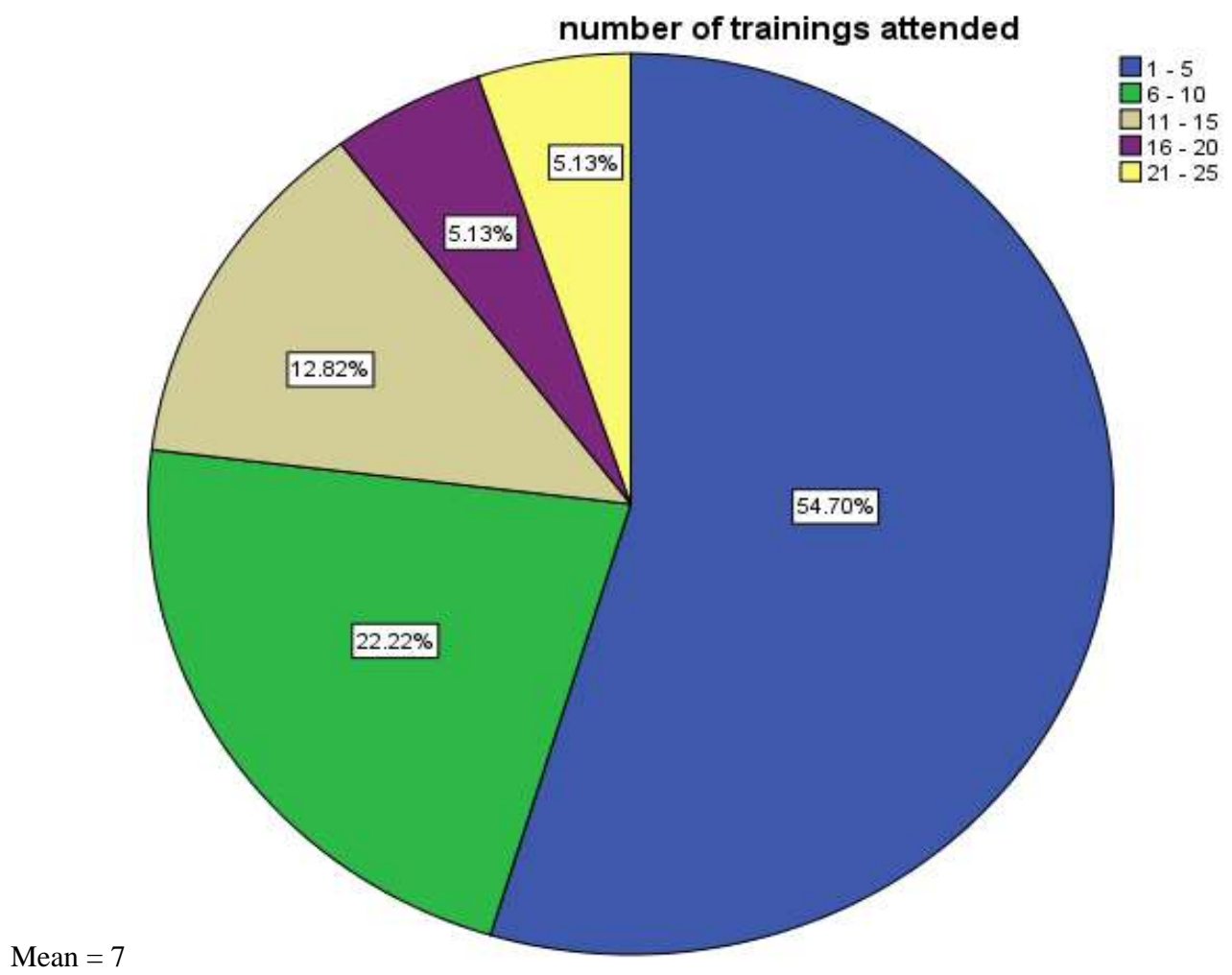

Figure 6: Numbers of Professional Trainings Attended by the Extension Agents

As illustrated in Figure 6, majority (54.7\%) of the respondents have attended $1-5$ number of trainings within their years of service. The mean number of trainings attended by the respondents as shown in table $12 \mathrm{~b}$ is 7 trainings. This implies that the respondents have gotten quite an amount of capacity building and trainings and therefore are expected to be competent in some of their tasks since the higher the number of trainings one attended, the more competent the person is likely to be.

Training Needs Analysis of Extension Agents

Table 2 contains three checklists; organizational level checklists, team level checklists and process and procedure checklist. These checklists contain some sets of questions that were answered by the respondents which determined if there was need for training at an organization level, team level and also process and procedures level. The mean frequency and percentages of each element is recorded in the Table. If the respondents answered "yes" in most of the questions then the researcher can proceed with the skill gap analysis to find out the specific areas of need for training. 
Table 2: Training Needs Analysis (n=117)

\begin{tabular}{|c|c|c|c|}
\hline & Yes & No & Not sure \\
\hline \multicolumn{4}{|l|}{ Organizational level checklist: } \\
\hline Do you understand the KNARDA's needs? & $97(82.9)$ & $8(6.8)$ & $12(10.3)$ \\
\hline Do you think there are any problems of KNARDA that can be solved by training? & $105(89.7)$ & $8(6.8)$ & $4(3.4)$ \\
\hline Can you identify future skill sets that will be required? & $73(62.4)$ & $13(11.1)$ & $31(26.5)$ \\
\hline \multicolumn{4}{|l|}{ Team level checklist: } \\
\hline Can you identify skill gaps within your team? & $87(74.4)$ & $7(6.0)$ & 23(19.7) \\
\hline Do you have appraisals and review meetings in place? & $93(79.5)$ & $16(13.7)$ & $8(6.8)$ \\
\hline Do you feel your team is well prepared for the future? & $90(76.9)$ & $7(6.0)$ & $20(17.1)$ \\
\hline Can you identify team wide training needs? & $86(73.5)$ & $17(14.5)$ & $14(12.0$ \\
\hline \multicolumn{4}{|l|}{ Process and procedures checklist: } \\
\hline \multicolumn{4}{|l|}{ Do you have the following selection and recruitment processes; } \\
\hline Job description regularly reviewed & $86(73.5)$ & $22(18.8)$ & $9(7.7)$ \\
\hline Job specification regularly reviewed & $74(63.2)$ & $28(23.9)$ & $15(12.8)$ \\
\hline \multicolumn{4}{|l|}{ Do you have the following training and development procedures; } \\
\hline Training needs analysis & $81(69.2)$ & $21(17.9)$ & $15(12.8)$ \\
\hline Compulsory training & $77(65.8)$ & $33(28.2)$ & $7(6.0)$ \\
\hline The opportunity to request for training & $81(69.2)$ & $25(21.4)$ & $11(9.4)$ \\
\hline Developed training plans & $88(75.2)$ & $14(12.0)$ & $15(12.8)$ \\
\hline Training matrix & $74(63.2)$ & 21(17.9) & $22(18.8)$ \\
\hline Give feedbacks after training & $90(76.9)$ & $22(18.8)$ & $5(4.3)$ \\
\hline
\end{tabular}

Source: Field Survey, 2019

It can be seen from Table 2 that majority $(82.9 \%$ \& 89.7\%) of the respondents understood the organization's needs and think that problems of the organization can be solved through training. It can also be deduced from the team level checklist that more than half $(73.5 \%)$ of the respondents can identify team wide training needs within their team. Majority of the respondents agree that they had good processes and procedures in place which include; formal interview process to confirm they have skill (65.0\%), job description regularly reviewed $(73.5 \%)$, had compulsory trainings $(65.8 \%)$ and have completed the training matrix $(76.9 \%)$. The table further shows that majority $(69.23 \%)$ answered yes to the questions which means there is need for skill gap analysis to find out what skills are needed now and, in the future, to improve the capacity building of the respondents. 


\section{Competence Level of Extension Agents}

This study sought to evaluate the professional competence level of the extension agents in the study area prior to the assessment of their training needs. The respondents were asked to rate themselves in relation to how competent they felt to be in each of the aspects. It can be deduced from Table 16 that the respondents' most competent aspects were learning initiative and enterprise (mean=3.41), team work (3.24), communication (3.15), problem solving (3.09), self-management (3.07) and technology (3.04). Their least competent aspects were in leadership (2.96) and planning and organizing (2.91).

Table 3: Professional Competence Level of the Extension Agents (n=117)

\begin{tabular}{|c|c|c|c|c|c|c|}
\hline Skill Area. & Very Poor & Poor & Good & Very Good & Excellent & Mean \\
\hline Learning Initiative and enterprise & $3(2.6)$ & $17(14.5)$ & $39(33.3)$ & $45(38.5)$ & 13(11.1) & 3.41 \\
\hline Team work & $11(9.4)$ & $20(17.1)$ & $33(28.2)$ & $36(30.8)$ & $17(14.5)$ & 3.24 \\
\hline Communication & $9(7.7)$ & $17(14.5)$ & $50(42.7)$ & $30(25.6)$ & $11(9.4)$ & 3.15 \\
\hline Problem Solving & $7(6.0)$ & $37(31.6)$ & $30(25.6)$ & $24(20.5)$ & $19(16.2)$ & 3.09 \\
\hline Self-Management & $10(8.5)$ & $26(22.2)$ & $42(35.9)$ & $24(20.5)$ & $15(12.8)$ & 3.07 \\
\hline Technology & $14(12.0)$ & $24(20.5)$ & $34(29.1)$ & $33(28.2)$ & $12(10.3)$ & 3.04 \\
\hline Leadership & $14(12.0)$ & $25(21.4)$ & $37(31.6)$ & $34(29.1)$ & $7(6.0)$ & 2.96 \\
\hline Planning and organizing & $17(14.5)$ & $24(20.5)$ & $41(35.0)$ & $22(18.8)$ & 13(11.1) & 2.91 \\
\hline
\end{tabular}

Source: Field survey, 2019

As declared by the extension agents, learning initiative and enterprise (mean $=3.41$ ) is one of the most important skills the EOs should be competent in. Their level of competence in such task can determine what they pass down to the farmers. Team work (mean $=3.24)$ is perceived to be the backbone of extension work as it is always required in each step of the work. Communication (mean $=3.15$ ) was ranked third in perceived professional competence of the extension agents and is highly required in the extension job. In organizations like Extension organization, both oral and written communication is an element that can't be dealt without especially when dealing with the farmers (Adelanwa, 2002 in Okeowo, 2015).

Competence in problem solving (mean $=3.09$ ) is equally highly demanded as the farmers are always looking towards the Extension Agents to get expert judgments of their problems and challenges (Adelanwa, 2002 in Okeowo, 2015). It is expected of any Extension Agent to be competent in self-management as that will give the impression that they can discharge their duties properly and timely. The extension agents' competence in understanding technology (mean $=3.04)$ is the first step taken before disseminating such technology to the farmers. Though leadership and planning and organization had the least score, looking at the means (2.96 and 2.91) will give the understanding that the extension agents were beyond average in such elements.

Strengths, Weaknesses, Threats and Opportunities (SWOT) Analysis

Table 4 identifies the Strengths, Weaknesses, Opportunities and Threats (SWOT) with regards to extension agents in Kano State. As indicated in the table 4, Strengths and Weaknesses are of internal origin while Opportunities and Threats are of external origin. Also, Strengths and Opportunities are of positive nature which means they will contribute to the development of the organization and therefore should be promoted while Weaknesses and Threats as the name implies are of negative nature and should be avoided or at least limited to the barest minimum. 
Table 4: SWOT Analysis for Extension Agents in Kano State. (n=117)

\begin{tabular}{|c|c|c|c|}
\hline \multirow{2}{*}{$\begin{array}{ll} & \text { Positive } \\
\text { Strengths } & \end{array}$} & \multicolumn{3}{|c|}{ Negative } \\
\hline & Mean & Weaknesses & Mean \\
\hline Farmer development through group sessions (S1) & 3.15 & Ineffective management (W1) & 2.62 \\
\hline Farmer development through demonstration trials (S2) & 3.33 & $\begin{array}{l}\text { Poor implementation of policy formulation } \\
\text { (W2) }\end{array}$ & 3.04 \\
\hline Transferring information through regular interactions (S3) & 3.40 & $\begin{array}{l}\text { Top-down approach nature of organization } \\
\text { (W3) }\end{array}$ & 2.98 \\
\hline $\begin{array}{l}\text { Installing new ideas to the farmers thus improving their } \\
\text { farming skills (S4) }\end{array}$ & 3.26 & $\begin{array}{l}\text { Too many jobs with different specializations } \\
\text { expected (W4) }\end{array}$ & 3.12 \\
\hline $\begin{array}{l}\text { Participative action through working with farmers and } \\
\text { involving them in development process (S5) }\end{array}$ & 3.32 & Scarce resources (W5) & 2.86 \\
\hline $\begin{array}{l}\text { Service delivery through the regulation and management } \\
\text { of government support programs (S6) }\end{array}$ & 2.91 & Lack of finance (W6) & 2.83 \\
\hline $\begin{array}{l}\text { Well-structured service with suitably qualified officials } \\
\text { (S7) }\end{array}$ & 3.08 & Poor farmer development (W7) & 2.87 \\
\hline \multirow[t]{2}{*}{ Providing support to policy formulation (S8) } & 3.21 & Poor communication with farmers (W8) & 2.87 \\
\hline & & Poor communication within the service (W9) & 3.02 \\
\hline Opportunities & Mean & Threats & Mean \\
\hline $\begin{array}{l}\text { Improvement of knowledge through training provided } \\
\text { (O1) }\end{array}$ & 3.01 & $\begin{array}{l}\text { Lack of technology and information for agents } \\
\text { (T1) }\end{array}$ & 2.65 \\
\hline Increase in food security $(\mathrm{O} 2)$ & 3.05 & $\begin{array}{l}\text { The development of unproductive farmers } \\
\text { who cannot be commercial farmers (T2) }\end{array}$ & 2.67 \\
\hline Easy access to markets (O3) & 3.09 & $\begin{array}{l}\text { Competition between other departments and } \\
\text { Non-Government Organization in the same } \\
\text { area (T3) }\end{array}$ & 2.74 \\
\hline Easy access to other agriculturally-related industries $(\mathrm{O} 4)$ & 2.95 & Political will to effect change (T4) & 3.29 \\
\hline \multirow[t]{2}{*}{ Good communication skills with farmers (O5) } & 3.44 & $\begin{array}{l}\text { Interference of politicians into technical } \\
\text { aspects (T5) }\end{array}$ & 3.41 \\
\hline & & Too many superior agents (T6) & 3.32 \\
\hline
\end{tabular}

Source: Field survey, 2019

As shown in table 4, based on the means deduced the highest ranked strengths and weaknesses are S3 (mean = 3.4), S2 $($ mean $=3.33), \mathrm{S} 5($ mean $=3.32), \mathrm{W} 4($ mean $=3.12), \mathrm{W} 2$ $($ mean $=3.04)$ and W9 $($ mean $=3.02)$. Also, the highestranking opportunities include $\mathrm{O} 5($ mean $=3.44), \mathrm{O} 3$ (mean = 3.09) and $\mathrm{O} 2($ mean $=3.05)$ and the threats include $\mathrm{T} 5$ (mean $=$ $3.41)$, T6 $($ mean $=3.32)$ and $\mathrm{T} 4($ mean $=3.29)$ which ranked $1^{\text {st }}, 2^{\text {nd }}$ and $3^{\text {rd }}$ respectively. Some notable ranking between the strengths (S3), weaknesses (W4), opportunities (O5) and threats (T5) revealed that good communication skills with farmers (O5) come first, followed by Interference of politicians into technical matters (T5) ranked second. Transferring information through regular interactions (S3) and too many jobs with different specializations expected (W4) ranked third and fourth respectively.

\section{CONCLUSION}

This study conclude that extension agents were found to be poorly competent in some important professional skills which include leadership, and planning and demonstration. The study found out that the extension agents' strengths were mainly in transferring information through regular interactions with farmers and the development of those farmers through demonstration trials while their main opportunities were found to be good communication skills with farmers and easy access to market. The study further expressed the weaknesses of the extension agents as the high expectations on them despite having too many jobs with different specializations and threat as the interference of politicians into technical aspects. 


\section{RECOMMENDATIONS}

i. The study found out that extension service was male dominated. It is therefore recommended that the government should employ more female extension agents as the number of women farmers are increasing.

ii. The study discovered that more than half of the extension agents had diploma certificates. There is need for more programs like SAFE that collaborates with higher institutions to provide more opportunities for the extension agents to upgrade their educational qualifications so as cover the high number of extension agents with low educational qualifications.

iii. It was revealed in this study that the extension agents were average in most of the professional competencies and it is therefore recommended that in-service training should be planned for them in social and management science fields where the agents will be able to acquire basic knowledge in most of the areas of professional competencies, they were deficient in.

iv. In the study area, extension agents were found to seriously require training. It is advised that training needs analysis should be carried out for both newly recruited and also periodically to determine the training needs of the extension agents for their proper placement in the required training areas at any given period of time.

\section{REFERENCES}

Abbas, M., Lodhi, T. E., Bashir, A. and Mahmood, M. A. (2008). Dissemination of Wheat Production Technologies and Interface of Out-Reach Efforts with Farmers. Journal of Agricultural Research, 46(1): 99-108.

Azizah, S. (2011). Training needs assessment of agricultural extension officers in animal husbandry department of Malang regency, East Java-Indonesia. Journal of Agricultural Extension and Rural Development, 3: 147-152.

Chikaire, J. U., Emerhirhi, E., Anyoha, N. P. and Onoh, P. A. (2018). Perceived Competencies of Agricultural Extension and Advisory Services Providers in Building Rural Farmer Capability in Imo State Nigeria. International Journal of Research in Agriculture and Forestry, 5 (6):25-32.

Crowder, L. V. (1996). Assessment of Preservice and Inservice Extension Education. Agricultural Extension and Education Service (SDRE). FAO Research, Extension and Training Division. 3p. Also available at www.fao.org/sd/exdirect/exan001.htm.
Due, J. M., Mageyane, F. and Temu, A.A. (1997). Smallholder Farmers' Perception of Extension by Gender in Tanzania. World Development, 25 (5): 713-725.

Food and Agriculture Organization (FAO) (1990). Global Consultation on Agricultural Extension.

Food and Agriculture Organization (FAO) (2001). Global Consultation on Agricultural Extension Services. A Journal of Extension Education, 2(3): 11-14.

Haruna, S.K. and Abdullahi Y.M. (2013). Training of Public Extension Agents in Nigeria and the Implication of the Government's Agricultural Transformation Agenda. Nigerian Journal of Agricultural Extension, 17(2): 98-104.

Jasim Mohammed Saleh, Norsida Man, Ahmad Hamdan Lafta, Majeed Hadi Saleh, Salim Hassan, Nolila Moha Nawi and Bassim Haleem Kshash, (2016). A Review: Training Requirement of Agriculture Extension Officers in Iraq. Asian Journal of Applied Sciences, 9: 3440.DOI: $\underline{10.3923 / a j a p s .2016 .34 .40}$

Kano State (2008). Kano State Government Official Diary, Information Department.

Mahaliyanaarachchi, R. P. and Bandara, R. (2006). Commercialization of Agriculture and Role of Agricultural Extension. Sabaragamuwa University Journal, 6(1): 13-22.

Miller, R. L. and Brewer, J. D. (2003). A-Z of Social Research. SAGE Publication Ltd. London.

National Population Commission (NPC), (2006). Human Population Figure of 2006 Census in Nigeria. Federal Republic of Nigeria.

Okeowo, T. A. (2015). Analysis of Competency and Training Needs among Agricultural Extension Personnel in Lagos State. International Journal of Forestry and Horticulture (IJFH), 1(2):14-21.

Olofin, E. A. (1987). Some Aspects of the Physical Geography of the Kano Region and Related Human Responses Series. Geography Department Bayero University Debis Standard Printers, Kano, Nigeria.

Omoregbee F. E. and Ajayi M. T. (2009): Assessment of Training Needs of Extension Staff of Agricultural Development Programme (ADP), Edo State, Nigeria. AgroScience Journal of Tropical Agriculture, Food, Environment and Extension, 8(2):97-103. 
Ovwigho, B. O. and Ifie, P. A. (2009). Principles of Youth Development in Africa. Benin-City: Ethiope Publishing Corporation.

Sadia J. M. and Abdul M. M., (2016): Farmers Awareness on Effective Delivery of Farm Information through ICT Medical Extension Service in Bangladesh. European Scientific Journal, 12: $1857-7431$

Safdar, Z. (2005). Role of Extension Agent in the Diffusion of Onion and Tomato Crop. A Case Study of Four Selected Villages of UC Sakhkot Malakand Agency. M. Sc. (Hons) Thesis, NWFP Agricultural University Peshawar.

Sanga, C., Kalungwizi, V. J. and Msuya, C. P. (2013). Building an Agricultural Extension Services System Supported by ICTs in Tazania: Progress Made, Challenges Remain. International Journal of Education and Development Using Information and Communication Technology (IJEDICT), 9(1):80-99.

Youdeowei, A. and Kwarteng, J. (2006). Tool Kit for the Production of Agricultural Extension Materials. Guide Book, CTA Wageningen, The Netherlands. 50pp. 